\section{Decentrale overheden en beleidsinnovaties ter ondersteuining van actief burgerschap in de productie van lokaal opgewelkte duurzame energie}

Beau Warbroek \& Thomas Hoppe

Terwijl decentrale overheden al langere tijd ervaring hebben met samenwerkingsverbanden met lokale gemeenschappen op het gebied van duurzame ontwikkeling, neemt de urgentie van de klimaatproblematiek toe en ontwikkelt de burger zich tot een gelijkwaardige partner. De convergentie van deze twee drijfveren vergt een innovatieve manier van handelen waarin het optreden van decentrale overheden een belangrijke factor is voor het succes van lokale duurzame energieprojecten waar burgers actief bij betrokken zijn of worden betrokken. Dit artikel belicht de wijzen waarop decentrale overheden innoveren met beleid voor de ondersteuning van actief burgerschap in de productie van lokaal opgewekte duurzame energie en verkent de barrières die daarbij optreden. De auteurs analyseren twee cases op verschillende bestuurslagen: 'De Energie-werkplaats' (provincie Fryslân) en 'Armhoede duurzaam energie landschap' (gemeente Lochem). De cases laten zien dat beleidsinnovaties kristalliseren op zowel 'armlengte' afstand als binnen de directe invloedssfeer van de (decentrale) overheidsorganisatie. Innovatie vindt echter plaats bij de gratie van de ruimte binnen het bestaande institutionele kader en van het politiek (en ambtelijk) bestel. Hierbij kunnen zowel formele richtlijnen (zoals beleid of regelgeving) als personen en informele werkwijzen die een rol hebben in de traditionele uitvoering van beleid, een productieve interactie tussen (actieve) burger en overheid belemmeren.

\section{$1 \quad$ Inleiding}

Op 12 december 2015 heeft de internationale gemeenschap in het Akkoord van Parijs wederom bevestigd dat klimaatverandering moet worden aangepakt en dat alle overheidslagen hierin een rol spelen. Vooral decentrale overheden (gemeenten en provincies) spelen daarin een belangrijke rol. Duurzaamheidsproblemen manifesteren zich met name op dit schaalniveau (o.a. Bulkeley \& Kern, 2006). Deze onderkenning is beleidsmakers en -wetenschappers niet vreemd; al in 1992 vond het haar intrede in de 'Lokale Agenda 21'. In dit supranationale initiatief van de Verenigde Naties werd een beroep gedaan op lokale overheden en werd gezocht naar nieuwe samenwerkingsverbanden tussen lokale actoren en overheden (Coenen, 2009). In evaluaties van de Lokale Agenda 21 stond de vraag vaak centraal naar 'wat dit betekent voor de rol van decentrale overheden' (zie onder meer Sancassiani, 2005; Selman, 1998; Collier, 1997).
Terwijl decentrale overheden al langere tijd ervaring hebben met samenwerkingsverbanden met lokale gemeenschappen op het gebied van duurzame ontwikkeling, neemt de urgentie van de klimaatproblematiek toe en ontwikkelt de burger zich tot een gelijkwaardige partner. De convergentie van deze twee drijfveren vergt een innovatieve manier van handelen waarin het optreden van decentrale overheden een belangrijke factor is voor het succes van lokale duurzame energieprojecten waar burgers actief bij betrokken zijn of worden betrokken (Hoppe e.a., 2015a; Van der Schoor \& Scholtens, 2015).

Niettemin zijn veel decentrale overheden enerzijds op zoek naar een nieuwe rolneming om samen te werken met duurzame energie-initiatieven die vanuit actie burgerschap ontstaan (Oskam, 2012; Bolhorst e.a., 2015; Elzenga \& Schwencke, 2015), en anderzijds zijn overheden op zoek naar mechanismen om actief burgerschap bij de productie van lokaal opgewekte duurzame energie te mobiliseren (Evans e.a., 2006; Bulkeley \& Kern, 2006; Hawkins \& Wang, 2012). De onderliggende 'nieuwe manier van werken' wordt omschreven als een faciliterende rol, waarin vaak andere middelen en instrumenten worden gebruikt dan de 'oude manier van werken'. In plaats van 'te roeien' (het leveren van diensten) én 'te sturen' (vaststellen van beleidsdoelen) beweegt de overheid dan naar een constellatie waarin publieke diensten worden uitgevoerd door de private en/of de 'derde' sector, en wordt er gezocht naar nieuwe bestuursmodellen (Osborne \& Gaebler, 1992; Jordan e.a., 2005; Sanders e.a., 2014). De sturingsfilosofie beschreven in het rapport 'De energieke samenleving' sluit hier vrijwel naadloos op aan (PBL, 2011). Maarten Hajer stelt in dit rapport dat in deze manier van sturen de maatschappelijke dynamiek als uitgangspunt wordt genomen in processen van beleidsvorming en niet als laatste wordt geconsulteerd, om zo verduurzaming te realiseren. De burger treedt op als producent in plaats van passief subject en de overheid geeft ruimte aan samenwerkingsinitiatieven tussen instellingen, burgers en
bedrijven.

In deze sturingsfilosofie is in het bijzonder het lokale speelveld een belangrijke schaal (PBL, 2011). Niettemin hangt het toekomstperspectief van actief burgerschap in de productie van lokaal opgewekte duurzame energie voor een belangrijk deel af van de institutionele en beleidsregels die dit speelveld bepalen (Hoppe e.a., 2015b: 165; Oteman e.a., 2014). Decentrale overheden kunnen hier een prominente rol in spelen door gunstige condities te creëren (Hoppe \& Van den Akker, 2014; PBL, 2011). In dit artikel staat daarom de volgende onderzoeksvraag centraal: Op welke wijzen experimenteren en innoveren gemeente en provincie met beleid voor de ondersteuning van actief burgerschap in de productie van lokaal opgewekte duurzame energie, en welke barrières treden daarbij op?

Onze aandacht richt zich in dit artikel op de tweede en derde generatie van actief burgerschap, ${ }^{1}$ respectievelijk: (1) 'van bovenaf' geïnitieerde interactieve beleids-

1 Lenos e.a. (2006) onderscheiden drie generaties in beleid ten aanzien van burgerparticipatie. De eerste generatie burgerparticipatie kenmerkt zich door inspraak van burgers in beleid. De tweede en derde generatie zijn genoemd in de tekst. 

een aanpak 'van onderop' waarin zij een eigen idee zelf uitvoeren (Lenos e.a., 2006). In onze conceptualisatie van actief burgerschap is de term 'co-creatie' gereserveerd voor initiatieven waarin in een vroege fase burgers de kans krijgen beleid (zowel inhoudelijk als procesmatig) mede vorm te geven. Co-productie wijst op initiatieven waarin burgers betrokken worden bij beleidsimplementatieprocessen waarin voorheen het primaat vooral berustte bij de overheid (Voorberg e.a., 2015).

\section{Beleidsinnovatie}

In een theoretisch kader over beleidsinnovatie (toegepast in het domein van klimaatbeleid) staat het argument centraal dat (decentrale) overheden een cruciale rol hebben in het wegnemen van barrières op het terrein van klimaatbeleid (Jordan \& Huitema, 2014a; 2014b). Het wetenschappelijke debat dat daarbij wordt gevoerd, wordt echter overwegend gevoerd vanuit een 'governance'-perspectief (o.a. Hale \& Roger, 2014; Hoffmann, 2011). Deze zienswijze oriënteert zich voor namelijk op horizontale machtsconstellaties en netwerkconstructies waarin de rol van de overheid in de maatschappij minder centraal staat. In reactie hierop pleiten Jordan en Huitema (2014a; 2014b) voor een - hernieuwde - focus op de capaciteit van overheden om beleidsinnovaties te ontwikkelen waarmee 'governance'lacunes kunnen worden weggenomen (zie ook Vrielink \& Verhoeven, 2011). Deze literatuur over beleidsinnovatie wordt door de auteurs onderverdeeld in drie perspectieven, te weten: (1) het proces van uitvinden van beleid met een (daadwerkelijk) vernieuwend karakter (inventie), (2) de processen die leiden tot brede ingebruikname van de beleidsinnovatie (diffusie) en (3) de geprojecteerde en/of werkelijke effecten van de beleidsinnovatie waarin gekeken wordt in hoeverre het innovatieve beleid daadwerkelijk het gewenste effect heeft (effecten) (Jordan \& Huitema, 2014b, p. 717). De definitie van beleidsinnovatie luidt als volgt: 'het proces en/of product van de zoektocht naar het ontwikkelen van (i) nieuw en/of (ii) (breed) in gebruik genomen en/of (iii) effectief beleid, ten aanzien van bestaand beleid dat onder de maat presteert' (Jordan \& Huitema, 2014c: 915). De definitie laat zien dat een beleidsinnovatie als innovatief geduid kan worden vanuit één of meer perspectieven.

Dit artikel belicht beleidsinnovatie voornamelijk vanuit de perspectieven van 'inventie' en 'effecten'. Enerzijds willen we vaststellen of decentrale overheden daadwerkelijk met beleid innoveren of dat er enkel sprake is van 'oude wijn in nieuwe zakken'. Anderzijds willen we vaststellen wat de effecten van beleidsinnovaties zijn. Er is sprake van beleidsinnovatie als 'inventie' wanneer het beleidsinstrument (of elementen daarvan) daadwerkelijk nieuw is voor beleidsvoerende instanties en daarmee afwijkt van het bestaande beleidsspectrum in een specifiek beleidsdomein.

schap bij de productie van lokaal opgewekte duurzame energie heeft implicaties voor gangbare werkwijzen en verhoudingen tussen burger en overheid. Deze vinden plaats in een institutionele omgeving. Door invloed van beleidsinnovaties kan deze institutionele omgeving (iets) veranderen waardoor gunstige voorwaarden kunnen worden gecreëerd waarmee burgers in staat worden gesteld hun eigen duurzame energie op te wekken. Zonder beleidsinnovaties is een institutionele omgeving hier vaak nog niet op aangepast, en ontbreken gunstige condities om actief burgerschap te ondersteunen. Een bestaande institutionele omgeving kan ook de totstandkoming en uiteindelijk de implementatie en (daarmee de) effecten van beleidsinnovatie beïnvloeden, door bijvoorbeeld de aanwezigheid van bureaucratie, bestaande beleidskaders, weinig verandergezinde ambtenaren, of bestaande politiek-bestuurlijke preferenties voor hiërarchische sturingsmodellen (zie onder meer Taylor, 2003; Lowndes \& Sullivan, 2004; Head, 2007). Als gevolg hiervan kunnen er dillema's en fricties ontstaan bij overheden die innoveren met beleid, zoals de verhouding tussen 'loslaten' en 'conditioneren' of de keuze over het in te zetten instrument (bijvoorbeeld een subsidie of het geven van voorlichting) ten aanzien van actief burgerschap. In dit artikel worden de effecten van een beleidsinnovatie vooral beschouwd met aandacht voor de effecten op de institutionele omgeving waarin het instrument wordt toegepast. Aanvullend hierop wordt er, zij het op verkennende wijze, aandacht besteed aan de wijze waarop een beleidsinnovatie bijdraagt aan het behalen van de beoogde beleidsresultaten.

Om een 'divers' kijkje in de keuken te geven in de praktijk van hoe decentrale overheden omgaan met actief burgerschap in lokale duurzame energieproductie, en welke beleidsinnovaties daarbij een rol spelen, worden in dit artikel twee cases geanalyseerd op twee verschillende bestuurslagen. In de eerste plaats wordt de casus 'De Energie-werkplaats' (EWP) gepresenteerd. Dit is een loket op provinciaal niveau dat ondersteuning biedt voor lokale initiatieven in Fryslân. In de tweede plaats wordt de casus 'Armhoede duurzaam energie landschap' (ADEL) gepresenteerd. Dit gaat om een project gestart door de gemeente Lochem ter ondersteuning van een burgerinitiatief teneinde een duurzaam energielandschap te realiseren. Deze casusselectie onderkent dat EWP en de provincie Fryslân meer op afstand staan van lokale burgerinitiatieven en wel ondersteuning kunnen bieden, maar minder geschikt zijn om actief burgerschap te bewerkstelligen dan dat een gemeente dat op lokaal niveau kan. In die zin speelt bij de casus van de gemeente Lochem het voordeel dat men dichter bij de burger staat en de overheid zodoende meer in staat is om actief burgerschap direct te ondersteunen. De cases zijn onderzocht aan de hand van de twee eerdergenoemde theoretische noties over beleidsinnovaties, te weten (1) 'beleidsinventie' en (2) 'effecten van beleidsinnovaties'. Voor beide cases zijn zowel primaire bronnen (interviews) als secundaire bronnen (o.a. beleidsdocumenten, vergader- en communicatiestukken) aangewend. 


\section{Casuiistiek}

3.1 Casus 1: De Energie-werkplaats (EWP)

In de provincie Fryslân is de ondersteuning van lokale energie-initiatieven 'op armlengte geplaatst' van de provinciale organisatie en gemeenten. Dit houdt in dat de beleidsimplementatie aangaande de ondersteuning van lokale initiatieven gedelegeerd wordt aan een externe, semi-onafhankelijke, niet-publieke, beleidsuitvoerende instantie, ${ }^{2}$ in dit geval de 'Energie-werkplaats'. Het programma Energie-werkplaats is in 2013 gestart als een loket dat 'raad en daad' biedt voor lokale energie-initiatieven (het loket deelt geen subsidies uit). Het programma, gefinancierd door de provincie, kwam voort uit een motie van de Provinciale Staten. Als cierd door de provincie, kwam voort uit een motie van de Provinciale Staten. Als reactie op de sterke toename van lokale energie-initiatieven en een dreigende
stagnatie door moeilijkheden omtrent de financiering van dit soort initiatieven, vroegen de Staten om te zorgen voor financiële ondersteuning op korte termijn. Naar aanleiding van de motie werd er $€ 1$ miljoen uitgetrokken uit de Vrij Aan(VAR) om initiatieven te faciliteren. Nadat de provincie had vastgesteld dat de lokale initiatieven moeite hebben om de slag te maken van idee naar vruchtbaar project, bleek het geplande energiefonds (Fûns Skjinne Fryske Enerzjy; FSFE) met $€ 90$ miljoen investeringskapitaal in beginsel niet geschikt. Het FSFE is een revolverend fonds dat innovatieve duurzame energieprojecten financiert. Lokale initiatieven komen dikwijls niet in aanmerking voor dit fonds omdat zij niet aan de voorwaarden voldoen (zoals het hebben van een sluitende businesscase). De provincie koos daarom niet voor directe financiële ondersteuning (van projecten van lokale energie-initiatieven), maar voor een aanpak waarbij het opbouwen van capaciteit en het verstevigen van de organisatiekracht centraal staan. De provincie merkte dit aan als 'een aanpak met brede spin-off om een versnelling in Fryslân te bewerkstelligen (Provincie Fryslân, 2014). Op kleine schaal worden er nog wel opstartsubsidies à $€ 2.500$ verleend aan lokale initiatieven.

De EWP - dat oorspronkelijk een werkgroep van Netwerk Duurzame Dorpen was (een kennisplatform met verschillende duurzaamheidsthema's, geïnitieerd door (een kennisplatform met verschillende duurzaamhelling dat Doarpswurk (een stichting die initiatieven ondersteunt die de duurzame leefbaarheid op het Friese platteland versterken) de samenwerking aanging met de Friese Milieu Federatie (FMF) om zo aan de vraag naar ondersteuning voor initiatieven te voldoen. Deze samenwerkingsvorm was een concreet antwoord op de wens van de Provinciale samenwerkingsvorm was een concreet antword op de wens van de Provinciale Staten om initiatieven te ondersteunen en werd grotendeels gefinancierd voor de jaren 2014 en 2015 (uit de VAR). In 2014 veranderde het speelveld waarin de EWP opereerde met de intrede van een nieuwe actor: Ús Koöperaasje. Ús Koöpe EWP opereerde met de intrede van een nieuwe actor: Us Kooperaasje. Us Koope-
raasje is een overkoepelende energiecoöperatie waarvan lokale initiatieven lid

2 De EWP voert geen overheidstaken uit, maar beleid. Daarom is er geen sprake van een zelfstan dig bestuursorgaan. Het niet-publieke element wijst erop dat de werkzaamheden van de EWP uitdig best worden door twee externe stichtingen en niet door een democratisch verkozen bestuursgevoerd worden doik twee ext 'Semi-onafhankelijk' wijst erop dat de stichtingen grotendeels orgaan of ambtelijk apparaat. 'Semi-onafhankeli hun eigen bedrijf voeren. kunnen worden. Op haar beurt is de koepelcoöperatie voor een derde deel eigenaar van het regionale energiebedrijf 'Noordelijk Lokaal Duurzaam'3 (NLD) om zo haar leden in staat te stellen lokaal opgewekte duurzame energie opnieuw te verkopen (de coöperatie fungeert als 'tussenpersoon' door klanten te werven en eventueel de facturering en incasso uit te voeren, de daadwerkelijke energieleverancier blijft in dit geval NLD). Leningen en subsidies van de provincie Fryslân en de gemeente Leeuwarden dienden als opstartkapitaal om Ús Koöperaasje (geesteskind van een gemeenteambtenaar, maar als privépersoon betrokken), door en voor inwoners, van de grond te krijgen. De facto werkten de koepelcoöperatie en de EWP vanaf 2014 samen om initiatieven te ondersteunen. In 2016 is het samenwerkingsverband echter geformaliseerd met een gezamenlijke subsidieaanvraag voor de uitvoering van een opvolgend ondersteuningsprogramma voor de komende jaren.

- 'Oude wijn in nieuwe zakken?'

De samenwerkingsstructuur tussen Doarpswurk, FMF en later Ús Koöperaasje kan enerzijds worden gekenmerkt als een beleidsinventie omdat middels de EWP twee bestaande semioverheidsorganisaties worden verenigd (en daarmee hun beschikbare kennis en expertise delen) die als grondslag hebben een nieuw doel te dienen. Anderzijds is er tussen de EWP en de provincie in principe enkel sprake van een (traditionele) subsidierelatie. Onder dit mandaat bemoeilijken organisatorische belangen en budgetkwesties de mogelijkheden voor beleidsinnovatie, aldus de betrokkenen. Door deze constructie werkt de EWP binnen de bestaande provinciale (en gemeentelijke) beleidskaders en in lijn met de bestaande institutionele structuur. Het inventieve karakter van de EWP ligt derhalve in het combineren van bestaande componenten om een nieuw doel te adresseren, oftewel 'oude wijn in nieuwe zakken', en niet zozeer in het daadwerkelijke samenwerkingsverband tussen de provincie en de EWP zelf. Dit is des te meer zo waar de EWP 'op armlengte' van het provinciale apparaat is gezet en de provincie hierdoor niet direct gemoeid is met het inventieve karakter van het inhoudelijke werk van de EWP.

- De energiewerkplaats als 'incubator'

De EWP heeft een praktische, 'hands-on' insteek en is in sterke mate responsief door relevante problemen aan te pakken. De beschikbare kennis van de FMF over marketing en communicatie en de expertise van Doarpswurk op het terrein van sociaal-procesmatige ondersteuning convergeren in de EWP en geven lokale initiatieven sociaal-organisatorische ondersteuning. Ús Koöperaasje complementeert deze ondersteuning met inhoudelijke expertise over duurzame energie. Ook levert de koepelcoöperatie een infrastructuur die de initiatieven op institutioneel vlak versterkt (door indirect wederverkoop mogelijk te maken) en bewerkstelligt het verdere standaardisering en professionalisering van dienstverlening (door bijvoorbeeld het aanbieden van promotiemateriaal en standaard statuten voor het

3 Een deel van de leningen voor Noordelijk Lokaal Duurzaam is verstrekt door de provincie Fryslân (uit de VAR). 

onder meer worden uitgevoerd, betreffen workshops en 'communities of practice' die veranderingen in de postcoderoos ${ }^{4}$ behandelen en advies bieden bij de aanvraag van SDE+-subsidies door lokale energiecoöperaties. Hiermee draagt de EWP bij aan de beoogde beleidsresultaten door capaciteit op te bouwen voor initiatieven die zich in de startfase bevinden. De EWP kan hiermee worden geduid als een beleidsinnovatie omdat het loket de beweging versnelt ${ }^{5}$ (een effect in de zin van een geleverde bijdrage aan het beoogde beleidsresultaat) en maatwerk biedt. Door lokale initiatieven inhoudelijk (met kennis en maatwerk) en sociaal-procesmatig te ondersteunen wijkt het instrument af van het bestaande beleidsspectrum voor lokale initiatieven dat zich vooral richt op financiële ondersteuning door innovatiefondsen - zoals het FSFE - en door het uitgeven van opstartsubsidies.

\subsection{Casus 2: Armhoede duurzaam energie landschap (ADEL)}

In de gemeente Lochem is in de periode van 2009 tot 2012 het project 'Armhoede duurzaam energie landschap' (ADEL) uitgevoerd. Het project werd gefinancierd door de gemeente Lochem nadat een fonds was verworven uit het 'Innovatieprogramma Klimaatneutrale Stad' (IKS), een regeling die werd uitgevoerd door Agentschap NL. De officiële doelstelling van het ADEL-project was het realiseren van een duurzaam energielandschap - in casu het gebied 'Armhoede' - dat bijdraagt aan klimaatneutraliteit, (economische) waarde toevoegt aan het gebied en van onderaf georganiseerd is. In deze casus is de beleidsinnovatie de zogenoemde 'DEL'-aanpak, een ontwerpproces voor duurzame energielandschappen waarin burgerparticipatie en procesinnovatie centraal staan (Damen, 2014; Hoppe \& Van den Akker, 2014).

Het ADEL-project paste in de visie van de gemeente Lochem om in 2030 'klimaatneutraal' (netto geen broeikasgasemissies) te worden. Daartoe zouden vier terreinen een zogenoemd 'duurzaam energielandschap' (DEL) moeten worden. Het buurtschap Armhoede was de eerste daarvan en zou als rolmodel (qua organisatie, aanpak, bedrijfsmodel en leidraad) moeten dienen voor de drie later te volgen energielandschapsprojecten. De gemeente was op zoek naar een nieuwe besturingsstijl waarin meer ruimte gegund zou worden aan burgers om zelf verantwoordelijkheid te nemen en op afstand van de overheid besluiten te nemen. In het ontwerpproces werd deze ambitie voor een nieuwe besturingsstijl geconcretiseerd door lokale bewoners van Armhoede te betrekken in de besluitvorming rondom duurzame energieopwekking in hun terrein. Deze aanpak zou daarmee een 'eigen' dynamiek, proces en inhoud stimuleren, en werd uitgevoerd vanuit de

4 De postcoderoos-regeling staat voor de Regeling Verlaagd Tarief bij collectieve opwek. De regeling geeft kleinverbruikers die samen eigenaar zijn van een hernieuwbare energie-installatie, een belastingkorting. De korting is gekoppeld aan de (aangrenzende) postcodes waarin de productieinstallatie zich bevindt.

5 Volgens de Lokale Energie Monitor 2015 heeft de provincie Fryslân de meeste energiecoöperaties per miljoen inwoners. Per februari 2016 zijn er 36 energiecoöperaties in Fryslân, de initiatieven op werkgroep-niveau niet meegeteld.

gedachte dat bewoners 'zelf aan zet' zouden zijn. De overheid zou daarbij een andere rol aannemen dan de traditionele 'top-down'-benadering. Voorts zou de conventionele rolverdeling tussen bewoners en overheid worden losgelaten en zouden zij elkaar als gelijkwaardige partners bejegenen. Voor de gemeente was vooral een ondersteunende en regierol voorzien (Damen, 2014; Hoppe \& Van den Akker, 2014).

In de aanpak van ADEL benutte de gemeente nadrukkelijk de bestaande sociale infrastructuur (in het bijzonder de aanwezigheid van dorpsraden), en werd om de communicatie en procesontwikkeling te ondersteunen gebruikgemaakt van procesbegeleiders en opbouwerkers (participatiemedewerkers). Laatstgenoemden hadden een rol als intermediaire schakel tussen gemeente en burgers. De neutrale procesbegeleiders zouden daarbij de condities scheppen, vertrouwde conventies doorbreken, en sociale problemen die passen bij de traditionele rolverdeling - maar efficiënte communicatie in de 'nieuwe situatie' in de aan de kaak stellen (Versteeg $8 x$ De Jonge-Wils, 2012). Tevens vormden de opbouwwerkers voor burgers een menselijk gezicht en aanspreekpunt namens de gemeente (dat anders als een abstract instituut werd gezien dat ver weg staat van de lokale gemeenschap). Voor zowel de opbouwwerkers als de wethouder die het project stimuleerde, gold dat zij er een proactieve werkwijze op nahielden. Bij het optreden van problemen stapten zij naar de burgers (met 'keukentafelgesprekken') toe om te polsen hoe de problemen ervaren werden en hoe ze gezamenlijk een oplossing zouden kunnen vinden (Hoppe \& Van den Akker, 2014).

\section{- Institutionele barrières}

Tijdens het project bleek dat de deelnemende partijen, burgers en bedrijven enerzijds en de gemeente anderzijds moesten wennen aan de nieuwe werkwijze van de ADEL-aanpak. Burgers leerden snel om te gaan met hun nieuwe - invloedrijkere rol. Deskundigen, experts en gemeenteambtenaren die deelnamen aan het pro ject, moesten wennen aan de 'mondige burger' als gelijkwaardige gesprekspartner. Ondertussen koesterden veel burgers een 'aangeboren wantrouwen' jegens de overheid en werden zij hierin gesterkt door de traagheid waarmee de gemeente hun aanvragen behandelde en de weinig transparante wijze waarop dit gebeurde (Versteeg \& De Jonge-Wils, 2012). Gedurende het project groeide er echter wederzijds vertrouwen, al was deze aan het einde van het project nog steeds als 'broos' aan te merken. De weerstand tegen de DEL-aanpak zat vooral aan de uitvoeringskant van de gemeentelijke (ambtelijke) organisatie. Niet alle betrokken ambtenaren waren het met de nieuwe aanpak eens, sommige zagen meer zeggenschap van burgers als bedreiging, en sommige verzetten zich ertegen. Tijdens de uitvoering van het project had de gemeente met regelmaat moeite om haar positie te bepalen en worstelde met haar rol in het proces (Versteeg \& De Jonge-Wils, 2012). Bovendien ontbrak het binnen de gemeentelijke organisatie aan duidelijke afspraken, waardoor de interactie (of het gebrek eraan) tussen de afdelingen regelmatig een struikelblok vormde voor de continuïteit (Hoppe $8 x$ Van den Akker, 2014). 


\section{- Is ADEL innovatief?}

De aanpak die centraal stond in ADEL, is inventief omdat deze sterk verschilt met de traditionele werkwijze en het beleidsspectrum van de gemeente ten aanzien van ruimtelijke ordening en lokale opwekking van duurzame energie. Het vernieuwende aspect (de 'DEL'-aanpak) was vooral gelegen in de procesmatige ondersteuning van co-creatieprocessen die ruimte liet voor stimulering van een 'eigen' dynamiek, proces en inhoud door actieve burgers. Daarbij werd binnen het energiedomein geëxperimenteerd met in de sociale en ruimtelijke beleidsdomeinen al eerder in zwang zijnde maatregelen als de inzet van "participatie- en opbouwmedewerkers' en vormen van procesmanagement.

Tevens is ADEL als een beleidsinnovatie te duiden wanneer haar effecten worden onderkend; het project vormde de basis voor de ontwikkeling van een gemeentebrede ondersteuningsaanpak (en -beleid) ten aanzien van het mobiliseren van burgers en het procesmatig ondersteunen van actief burgerschap in co-creatieprocessen (gericht op de ontwikkeling van een duurzaam energielandschap). Ook is het vertrouwen tussen burger en overheid gegroeid. Bovendien heeft de aanpak landelijk veel aandacht gekregen. Zo is het beloond met de GEN (gebied energieneutraal)-Impact studieprijs en heeft de verantwoordelijke wethouder in 2013 voor zijn aanpak de 'laatste zalmsnip'-trofee voor het op een innovatieve manier stimuleren van duurzame energie gewonnen. 'Hij, en de gemeente Lochem, lopen voorop in het gebruik van duurzame energie en zijn daarmee een lichtend voorbeeld voor andere gemeenten en wijken', aldus het prijs uitreikende comité (Hoppe \& Van den Akker, 2014). Dit wijst op een daadwerkelijk innovatief beleidsinstrument, gericht op het burgerinitiatief binnen de Nederlandse context.

Ook heeft ADEL bijgedragen aan beleidsvorming van de gemeente hoe actief burgerschap in andere lokale projecten te stimuleren, zowel in de zin van co-creatie als co-productie. Zonder dat ADEL als een 'beleidsexperiment' of 'proeftuin' had plaatsgevonden, waren deze beleidslijnen en projecten hoogstwaarschijnlijk nooit van de grond gekomen. In die zin stond ADEL in de gemeente Lochem aan de basis van het creëren van de condities waarin latere initiatieven in de beleidslijn 'actief burgerschap' van de grond konden komen. Ook bood het project de gemeente een mogelijkheid om te verkennen welke ambtelijke weerstand er bestond en om hiermee om te (leren) gaan. Ondanks alle inzet is er vooralsnog in directe zin geen duurzame energie opgewekt in het buurtschap Armhoede. Daarmee is het hoofddoel van het ADEL-project, de realisatie van een duurzaam energielandschap, in feite niet bereikt. Verder is gebleken dat een deel van de burgers in het Armhoede-buurtschap het project (en daarmee het experimenteren) na drie jaar zat waren. Dit geeft een indicatie voor een gebrek aan een bijdrage aan een langetermijnoplossing voor het effectief mobiliseren van actief burgerschap ten aanzien van de procesinnovaties die centraal stonden in de 'DEL-aanpak'.

\section{Conclusie}

Al vanaf het kabinet-Balkenende II in 2003 rolt de overheid maatregelen uit om de participatie van burgers te verhogen en actief burgerschap te bewerkstelligen. Het decentrale bestuur is echter na meer dan een decennium nog steeds op zoek naar antwoorden. Terwijl in de provincie Fryslân naarstig wordt gezocht naar een effectieve reactie op actief burgerschap, is er in Lochem een proces in gang gezet on in te zetten bij de en in te zetten bij de uitvoering van dienstverlening.

Tijdens deze zoektochten is er geïnnoveerd. Duidelijk wordt dat, hoewel er enkel een tipje van de sluier is gelicht, beleidsinnovatie ten aanzien van de ondersteuning van actief burgerschap in de productie van lokaal opgewekte duurzame energie geen eenzijdig fenomeen is. Zoals het beeld dat met de twee in dit artikel gepresenteerde cases is geschetst, kan dit zich onder meer kristalliseren 'op armganisatie. In beide cases zijn er invloedsfeer van de (decentrale) overheidsorinnovatieve aanpakken van de van het responsieve karakan de gemeente Lochem en provincie Fryslân geven blijk van het responsieve karakter van deze decentrale overheden.

Het blijkt echter dat innovatie plaatsvindt bij de gratie van de ruimte binnen het bestaande institutionele kader en van het politiek (en ambtelijk) bestel. Daarbij zijn elementen van hiërarchische sturingsmodellen en een dito institutionele omgeving dikwijls prominent aanwezig. Zo stellen Lowndes en Skelcher (1998) dat de fase waarin een partnerschap wordt gecreëerd - zoals die tussen de EWP en provincie Fryslân - een hiërarchisch karakter heeft waarbij formele processen en besluitvormingsprocedures leidend zijn. Tevens is het niet zonder reden Friese burgerinitiatieven geen solitaire dorpm in de jaren negentig noen plaatsen, terwijl dit 'street-level bur lijkt het erop dat Lipsky's beleid willen behouden, (1980) hun invloed op de uiteindelijke uitvoering van 2011) en de 'doe-demon als 'de energieke samenleving' (PBL, rijksrelaties, 2013) in hetratie' (Ministerie van Binnenlandse Zaken en Koninkde suggestie wekken in het discours over de relatie tussen overheid en samenleving ambtenaren zich hioneler en autonomer worden, en ten en strategischer naar dienen te schikken (Marinetto, 2003). Visiedocumenten en strategische agenda's die spreken over samenwerkingsverbanden (Van Bueren \& Steenhuisen, 2013), of projecten zoals ADEL, worden daarbij nog steeds als de politieke belangen vapaciteiten en kwaliteiten van het ambtelijke apparaat mee, metaforisch gezegd 'beleidskoker') en daaraan gerelateerd' die zijn oude territorium (of beter dedigen (Taylor, 2003). Hiermee gerelateerde competenties nog probeert te verformele richtlijnen (zon belang te onderkennen dat niet alleen (zoals beleid of regelgeving), maar ook personen en informele werkwijzen die een rol hebben in de traditionele uitvoering van beleid, een barrière kunnen vormen voor een productieve interactie tussen (actieve) burger en overheid. Deze personen en instituten zijn nog niet geënt op innovatieve beleids- 
de ruimte voor beleidsinventie en het effect geworden) burgers daarin, hetgeen dig beïnvloedt. zijn (en met heten voor beide cases voornamelijk sociaal-procesmatig van tie), zijn beleidsig op de tijdsdimensie die van belan social-procesmatig van aard tie), zijn beleidsinnovaties vooralsnog lastig belang is in ex post-beleidsevaluaeffecten (in de zin van 'beleidsoutput') lastig te evalueren. Niettemin zijn deze den de beleidsinnovaties mogelijk een fundament warderen als leerproces en biemogelijkerwijs in de toekomst vruchten kan afwent voor een bredere aanpak die ontwerp besteed aan de omgeving, de institutionele omdat meer aandacht kan ontwerp en implementatie van beleidsinnovaties gerichedding en maatwerk bij (uit henergie met actieve burgers. De landelijh gericht op stimulering van duur(uit het ADEL-project) heeft immers laten zijke aandacht voor de 'DEL'-aanpak op waardering kan rekenen.

\section{Literatuur} Speler of speelbal in de nieuwe verhoudingen tussen overheid, markt en samenleving',
Bestuurskunde, 2015/2, p. 3-16. ning', Bestuurswetenschappen, 2013/2, keley, H. \& K. Kern, 'Local governm 2, p. 23-39, many and the UK', Urban Studies, 2006/12, p. 2237-2259. climate change in Ger-

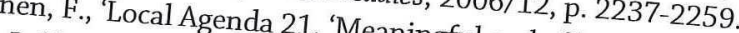

ollier, U $U$, 'Larticipation and better environmental decisive participation?', F. Coenen (ed.), diarity into authorities and climate protection in the Dordrecht: 2009, p. 165-182.

Damen, E., 'Evaluatie Innovcal environment, 1997/2, p. 39-57 Nieprogramma Klimaatneutr.

Elzenga, H. \& A.M. Schen, Nijmegen: 2014. Be, Hchwencke, 'Lokn' 2014.

Bestuurskunde, 2015/2, p. 17-26. Environmental Planning and Management, 2006/6, p. 849-867.
Hale, T. \& C. Roger, 'Orchestrationality', Journal of

International Organizations, 2014/1, p. 59-82.
thatkins, C.V. \& X (Sustainable de. 59 . 82 .

support networks in local sustainability initiatives', Public Works Marticipation and
2012/1, p. 7-29. Head, B.W., 7-29.

Political Science, 2007/3, p. 441.454. Participation on whose terms?', Australian Jounal of Hoffmann, M.J.

after Kyoto, Oxford, NY: 2011 .

Hoppe, T. \& D. Ora de Al: 2011.

vertrouwen schenkt aan de energieke samenleving', Prijkvoorbeeld van hoe lokaal bestuur ting local energy initiatives. Lessons from the best Lepping, 'Local governments supporHoppe, T., M.J. Arentsetherlands)', Sustainability, 2015a/tices of Saerbeck (Germany) Rooilijn, 2015b/2, \& M.P.T. Sanders, 'Lokale waarde, p. 1900-1931.

Jordan, A. \& D. Hb/2, p. 158-165. effects', Global Environmental Change, 2014a, p. 387-394.
Jordan, A. \& D. Huitema, 'Innovations in climate

Jordan, A and evaluation', Environmental Politics, 2014 . The politics of invention, diffuEnviro D. Huitema, 'Innovations in climate polib/5, p. 715-734.

Jordan, A., R.K.W. Wurzel 2014c/5, p. 906-925. perspective. Has gover \& Aito, 'The rise of 'nen

p. 477-496.

Lenos, S., P. Sturn

akk, Sturm \& R. Vis, Burgerparticipatie in gemeenteland. Quick scan van 34 cos

Lipsky, M., 'Street-level buramma's voor de periode 2006-2010. Quick scan van 34 coalitie1980.

Lowndes, V. \& C. Skelcher, 'The dynatic services', New York: sis of changing modes of dynamics of multi-organizationatp

Lowndes, V. \& H. Sullivan of governance', Public Administrational partnerships. An analylocal partnerships an, 'Like a horse and carriage or a fich , 1998/2, p. 313-333.

2004/1, p. 51-73 and public participation go together?', on a bicycle. How well do

Marineti, p. 51-73

into, M., 'Who wants to be an active citizen? The pol involvement', Sociology, 2003/1, p. 103-120.
Ministerie van Binnenlandse Zaken politics and practice of community

ter stimulering van een vitale samenleving, Den Hselaties, De doe-democratie. Kabinetsnota ming the public Gebler, Reinventing government. Haag: 2013.

Oskam, H., 'Rol gemeenten in

Oteman, M., M. Winten in lokale energiesecto

tives for renewabl \& J.K. Helderman, 'The institutio, 2012/6, p. 28-30.

and Denmark', Energy, Sy. A comparative case study of the of community initia-

Oude Vrielink, M.J. \& I. Verh, Sustainability and Society, 2014/11, Netherlands, Germany en Maatschappiij, I. Verhoeven, 'Burgerinitiatieven 14/11, p. 1-17.

Planbureau voor de Lij, 2011/4, p. 377-387.

Provincie

energie', Leeuwarden:

Sancassiani, Weeuwarden: 2014.

comm,. .' Local agenda 21 in Italy. An effect

Environment, 2005/2, p. 189-200

Sanders, M.P.T., $2005 / 2$, p. $189-200$

contests. Th.A. Heldeweg, E.G. Stra

regulatory legitimacy of interactive sustan \& J.F. Wempe, 'Energy policy by beauty

Schoor, T. van der \&. Energy, Sustainability and Society, 2014/4, st regional levels of the the transition 8 . Scholtens, 'Power to the people.

p. 666-675.

management, 1998/5 21. Substance or spin?', Journal of environmental planning and 
Versteeg, F. \& D. de Jonge-Wils, ADEL Lochem Eindrapportage Procesbegeleiding. Samen ber gen verzetten ......, CSTM/Oprit Duurzaamheid, Enschede/Rotterdam: 2012.

Voorberg, W.H., V.J.J.M. Bekkers \& L.G. Tummers, 'A systematic review of co-creation and co-production. Embarking on the social innovation journey', Public Management Review, 2015/9, p. 1333-1357.

\section{lokaal bestuur'}

Thomas Hoppe, Ellen van Bueren \& Maurits Sanders

Het vertrekpunt van dit themanummer was de rol van het lokaal bestuur bij de opgave van de energietransitie. Vijf uiteenlopende bijdragen hebben hier inzich in gegeven. Een eerste bevinding is dat de reeds in gang gezette verschuiving van (alleen) centrale energieopwekking naar (ook) decentrale energieopwekking invloed heeft op energiemarkten. Vooral op lokaal niveau is dit voelbaar en nieuwe institutionele uitgangspunten zorgen ervoor dat gemeenten weer als speler mee gaan doen in energievraagstukken. In feite heeft het lokaal bestuur thans een wonderlijke rol. Het staat vooral aan de zijlijn: het kan faciliteren, stimuleren, processen orkestreren, en door middel van vergunningverlening voor ruimtelijke projecten ook nog een beetje reguleren. Maar in vergelijking met de rol die de gemeente dertig jaar geleden had, is het toch een wat 'uitgeholde' positie. Destijds waren er nog gemeentelijke energiebedrijven die behalve voor productie ook verantwoordelijk waren voor distributie en levering van energie. De gemeente had daarmee naast een ondersteunende, faciliterende en regulerende rol ook een rol in de provisie van energie. Sinds die tijd is er echter veel veranderd; denk daarbij aan de liberalisering van de energiemarkt en de enorme schaalvergroting die heeft plaatsgevonden in energiemarkten. Niettemin zien we met de 'energietransitie' ten dele weer een terugkeer van de overheid in het systeem van energieproductie, -distributie en -consumptie. Dit is niet langer een centraal systeem, maar een gedecentraliseerd alternatief met een veel kleinere schaalgrootte.

In dit proces naar een gedecentraliseerd energiesysteem staat het lokaal bestuur voor een grote opgave om in een complexe omgeving met verschillende actoren, en met weinig sturende middelen om handen, invloed uit te oefenen op processen teneinde het publieke belang te dienen (met als waarden de opwekking en levering van schone energie, de betaalbaarheid van energie, en de zekerheid van energielevering). Formeel gezien zijn gemeenten thans geen partij in energiebeleid. Informeel vervullen gemeenten echter een cruciale rol in het realiseren van de internationaal overeengekomen doelstellingen ten aanzien van $\mathrm{CO}_{2}$-reductie, energiebesparing en vergroting van het gebruik van hernieuwbare bronnen. $\mathrm{Z}_{\mathrm{o}}$ is de verbetering van de energieprestatie in de bestaande voorraad van woningen en gebouwen onmisbaar voor het bereiken van de (inter)nationale energiedoelstellingen. Deze verbeteringen zijn echter niet afdwingbaar via nationale wet- en regelgeving. Lokale overheden, als 'dichtstbijzijnde' overheid, hebben daarmee een logische rol in het stimuleren van de eigenaren van woningen en gebouwen om energiemaatregelen te nemen. Ook zijn er gemeenten woningen en gebouwen hebben progressieve gemeenten - via het Klimaatakkoord en de Vereniging voor Nederlandse Gemeenten - deelgenomen aan de totstandkoming van het Natio nale Energie-akkoord in 2013. 